\title{
Meta Analisis Efektivitas Pembelajaran Fisika Secara Daring Menggunakan Virtual Laboratorium
}

\begin{abstract}
Author:
Abstrak:

Ambar Shinta Hapsari ${ }^{1}$

Ilham Rizki Fatur $\mathrm{R}^{2}$ Qatrunnida Fatimatu $Z^{3}$

Afiliation:

Universitas Islam

Negeri Syarif

Hidayatullah Jakarta ${ }^{1,2,3}$

Corresponding email ambar.hapsari18@mhs. uinjkt.ac.id

Latar belakang: Wabah Covid-19 mengubah seluruh aktivitas masyarakat, tak terkecuali pada bidang pendidikan. Kegiatan pembelajaran dilakukan secara daring, hal tersebut memunculkan tantangan tersendiri agar terciptanya kegiatan pembelajaran yang efektif. Penggunaan virtual lab menjadi solusi untuk pembelajaran Fisika agar berjalan secara efektif, walau dilakukan secara daring. Tujuan penelitian dilakukan untuk mengetahui efektivitas penggunaan virtual lab pembelajaran Fisika.

Metode penelitian: Metode yang digunakan adalah meta analisis, dengan mengumpulkan dan menganalisis artikel jurnal dengan tema topik yang sama.

Hasil penelitian: Hasil penelitian ini menunjukkan adanya keefektifan hasil pembelajaran dengan menggunakan virtual laboratorium untuk pembelajaran Fisika pada masa pandemi.

Histori Naskah: Submit: 2021-11-23 Accepted: 2021-11-24 Published: 2021-12-01

Kesimpulan: Disimpulkan bahwa penggunaan media virtual lab pada pembelajaran Fisika efektif pada masa pandemi. Efektivitas penggunaan virtual lab dibuktikan dengan meningkatnya minat belajar dan motivasi siswa. Hal tersebut berdampak juga pada hasil belajar yang meningkat.

This is an Creative Commons License This work is licensed under a Creative Commons Attribution-NonCommercial 4.0 International License

Kata kunci: Efektivitas Pembelajaran Fisika; Virtual Laboratorium; Wabah Covid-19

\section{Pendahuluan}

Akhir tahun 2019 merupakan akhir tahun yang tidak ingin dirasakan oleh banyak orang. Hal tersebut dikarenakan adanya wabah virus Covid-19 (pandemi Covid-19) yang menyebar secara bertahap ke seluruh dunia tak terkecuali Indonesia. Wabah ini membuat hampir semua aktivitas yang semula dilaksanakan secara tatap muka menjadi pertemuan tatap maya atau disebut dalam jaringan (Daring).

Sistem pembelajaran Daring memberikan tantangan tersendiri, dimana sekolah dan guru harus tetap mengoptimalkan kegiatan pembelajaran agar tetap efektif dan efisien. Hal tersebut sejalan dengan dikeluarkannya Kepmendikbud nomor 719/P/2020 yang berisi peraturan penyederhanaan kurikulum pendidikan, untuk jenjang pendidikan sekolah dasar sampai sekolah menengah selama pandemi Covid-19 (Kemdikbud, 2020). Penyederhanaan kurikulum ini dimaksudkan untuk mengurangi kompetensi dasar menjadi lebih sederhana sehingga dapat mengurangi beban siswa dan juga mempermudah guru dalam kegiatan pembelajaran. Meski terjadi penyederhanaan kurikulum terdapat target yang perlu dicapai berupa KI-3 mengenai pengetahuan dan KI-4 untuk kemampuan.
\end{abstract}


Hal tersebut menjadi tantangan untuk kegiatan pembelajaran agar dapat dilaksanakan seefektif dan seefisien mungkin terkhusus pada pembelajaran Fisika yang membutuhkan interaksi yang mendalam agar siswa tidak mengalami miskonsepsi. Giancoli menyatakan bahwa untuk bisa mengerti Fisika diperlukan observasi dan pengalaman yang didasarkan dari kegiatan keseharian siswa (Giancoli, 2005). Oleh karena itu kegiatan praktikum di laboratorium dapat menjadi salah satu solusi sehingga diharapkan bisa memberikan pengalaman siswa agar lebih mengerti.

Kegiatan belajar mengajar yang terkena dampak wabah tersebut salah satunya yaitu praktikum. Praktikum merupakan kegiatan ilmiah yang dapat menambahkan pemahaman seseorang di bidangnya. Praktikum biasanya dilakukan secara langsung di laboratorium dengan menggunakan alat dan bahan yang tersedia. Akibat wabah virus Covid-19, praktikum dialihkan secara virtual dengan menggunakan aplikasi atau website virtual laboratorium. Adanya virtual laboratorium menandakan bahwa perkembangan teknologi yang begitu cepat, sehingga seseorang harus mengikuti perubahan zaman yang ada. Berdasarkan perkembangan teknologi tersebut banyak peneliti yang mencoba untuk membuktikan keefektifan dari virtual laboratorium terutama pada masa pandemi. Penelitian Sebelumnya menguji keefektifan laboratorium terhadap berbagai macam hasil variabel penelitian, seperti hasil belajar, minat dan motivasi belajar. Banyaknya penelitian mengenai hal tersebut menjadi dasar dilakukannya penelitian ini. Penelitian ini merupakan penelitian studi literatur, yang mana bertujuan untuk membuktikan keefektifan penggunaan virtual laboratorium berdasarkan artikel atau penelitian terdahulu yang relevan.

\section{Studi Literatur}

Di awal pembelajaran Daring terdapat permasalahan pembelajaran yang menyebabkan learning loss, hal tersebut sesuai dengan studi kasus yang telah dilakukan oleh Adi dalam (Adi, Martono, \& Sudarno, 2021), dimana penyebab learning loss salah satunya adanya hambatan dari segi prasarana. Atas hal tersebut penggunaan media teknologi menjadi solusi terhadap sarana penanganan permasalahan pembelajaran secara Daring. Menurut (Hanifah Salsabila, Irna Sari, Haibati Lathif, Puji Lestari, \& Ayuning, 2020) Teknologi berperan sebagai media dalam interaksi pembelajaran daring, teknologi sebagai fasilitas dan penyampaian materi pembelajaran. Salah satu pemanfaatan teknologi dengan penggunaan virtual laboratorium sebagai media bantu pembelajaran. Virtual laboratorium didefinisikan sebagai lingkungan interaktif, sebagai sarana menciptakan dan melakukan eksperimen simulasi, terdiri dari domain dependent program simulasi, unit eksperimental disebut objek yang mencakup file data, alat yang beroperasi pada benda-benda, dan buku referensi (Hendra, 2015).

Guru pendidikan IPA khususnya Fisika, agar mampu melakukan kegiatan pembelajaran sesuai dengan RPP secara efektif berdasarkan materi yang diberikan seperti pelaksanaan praktikum. Maka guru dan siswa bisa melakukan kegiatan praktikum dengan memanfaatkan alternatif virtual laboratorium seperti PhET (Physics Education and Technology), aplikasi laboratorium maya kemendikbud, dan semacamnya.

Dalam praktiknya kegiatan praktikum dapat memberikan peluang belajar kepada siswa untuk membuktikan akan suatu teori yang telah ada, atau bahkan bisa menemukan materi baru dari proses praktikum. Hal tersebut sejalan dengan pendapat Woolnough \& Allsop dalam (Handayani, Tapilouw, \& Wulan, 2018) yang mengemukakan kegiatan praktikum bisa membangkitkan motivasi belajar, mengembangkan keterampilan dasar, serta dengan bereksperimen bisa menjadi sarana pembelajaran dengan pendekatan ilmiah, dan tentunya menunjang materi pelajaran. Sehingga pembelajaran Fisika tetap dapat terlaksana dengan pemanfaatan virtual laboratorium. 
Menurut penelitian (Rahma, 2020) aplikasi PhET (Physics Education and Technology) merupakan teknologi media laboratorium virtual dengan berbagai fitur didalamnya. Fitur berupa video, animasi, grafik, gambar, audio, dan teks. Aplikasi PhET dapat meningkatkan keaktifan pembelajaran Fisika, apabila dibimbing dengan baik oleh guru maka aplikasi PhET bisa bermanfaat untuk membuktikan teori Fisika yang ada serta mengurangi miskonsepsi pembelajaran Fisika.

Laboratorium maya, merupakan virtual laboratorium yang dibuat dan dikelola oleh KEMENDIKBUD. Virtual laboratorium tersebut, terdapat beberapa eksperimen yang dikelompokkan berdasarkan jenjang sekolah dan mata pelajaran. Mata pelajaran terdapat beragam jenis eksperimen, dimana bila memilih suatu eksperimen maka dalam fitur tersebut kita bisa mengatur beberapa variabel tools sesuai kebutuhan. Lab maya juga terdapat fitur teori, fitur tersebut lengkap berisi penjelasan dan rumus akan suatu materi eksperimen. Dengan begitu maka siswa dapat dengan mudah mengingat teori pembelajaran sebelum eksperimen. Terdapat pula fitur latihan soal, yang bisa menjadi bagian evaluasi pembelajaran ringan setelah melakukan kegiatan eksperimen.

\section{Metode Penelitian}

Jenis penelitian yang dipakai adalah jenis penelitian kualitatif dengan metode meta analisis. Meta analisis adalah bagian dari systematic review dengan mengidentifikasi, mengevaluasi semua penelitian yang relevan terhadap area topik atau fenomena tertentu yang akan diteliti (Hasanah, 2016).

Penelitian meta-analisis merupakan cara yang paling baik dalam menarik kesimpulan dari berbagai literatur tentang hasil penelitian (Syamsul, 2006). Pengumpulan data dalam penelitian yaitu dengan menelusuri beberapa artikel pada jurnal online. Kata kunci yang digunakan dalam penelusuran artikel adalah "Virtual Lab", "Pembelajaran Fisika", "Pandemi Covid 19".

Tujuan penelitian ini mengetahui dan menganalisis efektivitas pembelajaran Fisika di masa pandemi berbantuan media virtual lab. Prosedur penelitian menyesuaikan dengan langkah-langkah meta analisis yang disarankan oleh Sujipto. Langkah-langkah penelitian sebagai berikut, mengumpulkan data-data yang sejenis dalam penelitian, menganalisis dan mengevaluasi dari hasil pengumpulan data, dan menarik kesimpulan hasil data yang telah dianalisis (Saryono \& Ahmad, 2011).

\section{Hasil}

Hasil analisis dari 5 artikel E-Jurnal yang relevan terhadap penggunaan virtual lab pada pembelajaran Fisika didapatkan beberapa hasil positif dalam kegiatan pembelajaran Fisika dengan penggunaan media pembelajaran virtual lab. Data penelitian yang dianalisis oleh peneliti yaitu dengan menelaah serta menganalisis artikel E-Jurnal kemudian dipaparkan kembali oleh peneliti dengan cara deskriptif kualitatif. Berikut hasil analisis yang diperoleh peneliti:

Tabel 1. Data Hasil pre-test dan post-test pada Kelas Eksperimen

\begin{tabular}{|c|c|c|c|}
\hline \multirow{2}{*}{ No } & \multirow{2}{*}{ Parameter } & \multicolumn{2}{|c|}{ Kelas Eksperimen } \\
\cline { 2 - 4 } & & Pre-Test & Post-Test \\
\hline 1 & Jumlah Siswa & 17 & 17 \\
\hline 2 & Rerata & 68,18 & 89,65 \\
\hline 3 & Nilai Maks & 83 & 98 \\
\hline
\end{tabular}


Edu Cendikia: Jurnal Ilmiah Kependidikan

Volume: 1 | Nomor 3 | Desember 2021 | E-ISSN: 2798-365X | DOI: 10.47709/educendikia.v1i3.1190

\begin{tabular}{|c|c|c|c|}
\hline 4 & Nilai Min & 60 & 83 \\
\hline
\end{tabular}

Sumber: (Rahma, 2020).

Tabel 2. Data Hasil pre-test dan post-test pada Kelas Kontrol

\begin{tabular}{|c|c|c|c|}
\hline \multirow{2}{*}{ No } & \multirow{2}{*}{ Parameter } & \multicolumn{2}{|c|}{ Kelas Kontrol } \\
\cline { 2 - 4 } & & Pre-Test & Post-Test \\
\hline 1 & Jumlah Siswa & 17 & 78,18 \\
\hline 2 & Rerata & 55,41 & 86 \\
\hline 3 & Nilai Maks & 68 & 68 \\
\hline 4 & Nilai Min & 48 & \\
\hline
\end{tabular}

Sumber: (Rahma, 2020).

Pada tabel 1 dan 2 diketahui bahwa rerata, nilai maksimum, nilai minimun kelas eksperimen baik pre-test maupun post-test lebih besar dibanding kelas kontrol.

Tabel 3. Hasil Analisis Angket Minat Belajar Peserta Didik

\begin{tabular}{|c|c|c|}
\hline Data & Minat Belajar Awal & Minat Belajar Akhir \\
\hline Nilai Tertinggi & 79 & 79 \\
\hline Nilai Terendah & 38 & $\mathbf{6 7}$ \\
\hline Rata-rata & $\mathbf{6 0}$ & Cukup \\
\hline Kategori & Kurang Baik & \\
\hline
\end{tabular}

Sumber: (Dewa, Maria Ursula Jawa Mukin, \& Oktavina Pandango, 2020).

Tabel 4. Hasil Belajar Kognitif Peserta Didik

\begin{tabular}{|c|c|c|}
\hline Data & Hasil Belajar Kognitif Awal & Hasil Belajar Kognitif Akhir \\
\hline Nilai Tertinggi & 65 & 85 \\
\hline Nilai Terendah & 20 & 55 \\
\hline Ketuntasan (\%) & 0 & 82 \\
\hline Rata-rata & $\mathbf{4 3}$ & $\mathbf{7 4}$ \\
\hline Kategori & Kurang & Baik \\
\hline
\end{tabular}

Sumber: (Dewa et al., 2020).

Pada tabel 3 dan 4 diketahui bahwa nilai tertinggi, nilai terendah dan rata-rata minat belajar akhir siswa meningkat, begitupun dengan hasil belajar akhir kognitif siswa. 
Edu Cendikia: Jurnal Ilmiah Kependidikan

Volume: 1 | Nomor 3 | Desember 2021 | E-ISSN: 2798-365X | DOI: 10.47709/educendikia.v1i3.1190

Tabel 5. Respon Siswa

\begin{tabular}{|c|c|c|c|}
\hline No & Jenis Item & Bentuk Respon & \% \\
\hline 1 & Suasana Belajar & Menyenangkan & 96,88 \\
\hline 2 & Pembelajaran menggunakan virtual lab & Berminat & 90,63 \\
\hline 3 & Tes hasil belajar & Mudah & 87,5 \\
\hline
\end{tabular}

Sumber: (Abdul, 2021).

Tabel 6. Hasil Belajar

\begin{tabular}{|c|c|}
\hline Aspek & Hasil belajar \\
\hline Rata-rata & 81,6 \\
\hline Nilai terendah & 60 \\
\hline Nilai tertinggi & 100 \\
\hline Ketuntasan & 90,6 \\
\hline
\end{tabular}

Sumber: (Abdul, 2021).

Pada tabel 5 dan 6 dapat diketahui bahwa bentuk respon siswa terhadap suasana belajar dikatakan menyenangkan, minat belajar menggunakan virtual lab terindikasi tinggi dan tes hasil belajar tergolong mudah. Untuk aspek rata-rata, nilai terendah, nilai terendah dan ketuntasan terhadap hasil belajar tergolong baik.

Tabel 7. Kategori Minat Belajar Sebelum Menggunakan Media Pembelajaran Virtual Lab

\begin{tabular}{|c|c|c|c|c|}
\hline No & Interval & Frekuensi & Persentase (\%) & Interprestasi \\
\hline 1 & $\mathrm{X} \geq 54$ & 6 & $21,4 \%$ & Tinggi \\
\hline 2 & $47 \leq \mathrm{X}<54$ & 14 & $50 \%$ & Sedang \\
\hline 3 & $\mathrm{X}<47$ & 8 & $28,6 \%$ & Rendah \\
\hline
\end{tabular}

Sumber: (Asshalihin, 2021).

Tabel 8. Kategori Minat Belajar Setelah Menggunakan Media Pembelajaran Virtual Lab

\begin{tabular}{|c|c|c|c|c|}
\hline No & Interval & Frekuensi & Persentase (\%) & Interprestasi \\
\hline 1 & $\mathrm{X} \geq 57$ & 8 & $28,6 \%$ & Tinggi \\
\hline 2 & $51 \leq \mathrm{X}<57$ & 15 & $53,5 \%$ & Sedang \\
\hline 3 & $\mathrm{X}<51$ & 5 & $17,9 \%$ & Rendah \\
\hline
\end{tabular}

Sumber: (Asshalihin, 2021). 
Edu Cendikia: Jurnal Ilmiah Kependidikan

Volume: 1 | Nomor 3 | Desember 2021 | E-ISSN: 2798-365X | DOI: 10.47709/educendikia.v1i3.1190

Pada tabel 7 dan 8 diketahui persentase minat belajar mengalami peningkatan setelah menggunakan media pembelajaran virtual lab.

Tabel 9. Categorization of Motivational Values Using Virtual Laboratory

\begin{tabular}{|c|c|c|c|}
\hline Category & Formula & Amount & Presentation (\%) \\
\hline Very Low & $\mathrm{X} \leq 70$ & 0 & 0,0 \\
\hline Low & $70<\mathrm{X} \leq 93$ & 0 & 0,0 \\
\hline Medium & $93<\mathrm{X} \leq 117$ & 6 & 6,5 \\
\hline High & $117<\mathrm{X} \leq 140$ & 74 & 79,6 \\
\hline Very High & $140<\mathrm{X}$ & 13 & 14,0 \\
\hline Total & & 93 & 100,0 \\
\hline
\end{tabular}

Sumber: (Faris \& Dwikoranto, 2021).

Tabel 10. The score of student learning outcomes on Hooke's Law using a virtual laboratory

\begin{tabular}{|c|c|}
\hline Student learning motivation & Average score \\
\hline Medium & 39,29 \\
\hline High & 43,70 \\
\hline Very High & 44,00 \\
\hline
\end{tabular}

Sumber: (Faris \& Dwikoranto, 2021).

Pada tabel 9 dan 10 dapat diketahui persentase penggunaan virtual lab terindikasi tinggi pada motivasi dan hasil belajar Fisika siswa.

\section{Pembahasan}

Hasil analisis dari beberapa artikel pada E-Journal, dinyatakan terdapat efektivitas pembelajaran Fisika secara daring menggunakan virtual lab yaitu:

Penelitian yang dilakukan (Rahma, 2020) mengenai penggunaan virtual lab $\mathrm{PhET}$ terhadap hasil belajar siswa pada mata pelajaran Fisika. Diketahui tabel data hasil pre-test dan post-test dari kelas kontrol dan kelas eksperimen didapatkan nilai rerata pre-test kelas eksperimen lebih besar bernilai 68,18 dibanding kelas kontrol sebesar 55,41. Sedangkan nilai post-test kelas eksperimen bernilai lebih besar yaitu 89,65 dibanding kelas kontrol sebesar 78,18. Penggunaan virtual lab pada kelas eksperimen untuk pembelajaran Fisika dinilai lebih efektif dibandingkan dengan kelas kontrol yang tidak menggunakan virtual lab saat proses pembelajaran Fisika. Hasil analisis bahwa penggunaan virtual lab sebagai media pembelajaran cukup efektif di masa pandemi. Penggunaan media virtual lab PhET menghasilkan rata-rata skor hasil belajar siswa serta $\mathrm{N}$-Gain score lebih tinggi dibandingkan tidak menggunakan media virtual lab PhET. 
Hal ini sejalan dengan (Anitasari, Winarti, \& Rusmansyah, 2019) dengan penggunaan media aplikasi memunculkan peningkatan kegiatan belajar siswa, khususnya pembelajaran Fisika dengan berkurangnya miskonsepsi pada materi Fisika tertentu. Sehingga hasil belajar siswa pada mata pelajaran Fisika meningkat.

Penelitian yang dilakukan (Dewa et al., 2020) mengenai penggunaan virtual lab terhadap minat dan hasil belajar kognitif siswa pada pembelajaran Fisika secara daring. Diketahui hasil data persentase kategori minat belajar siswa menunjukan terjadi peningkatan minat belajar siswa dari kategori kurang sampai kategori cukup, dari keadaaan sebelum dan sesudah menggunakan virtual lab pembelajaran Fisika. Hasil analisis angket menunjukan rata-rata persentase minat belajar Fisika siswa meningkatan dari nilai 60 menjadi 67, berada pada kategori cukup. Hal tersebut sesuai dengan hasil kognitif pembelajaran Fisika siswa, sebelum menggunakan virtual lab dengan rata-rata nilai 43 menjadi 74, dari kategori kurang menjadi baik. Dapat ditarik kesimpulan bahwa penggunaan laboratorium virtual lab selama pembelajaran daring dapat memudahkan siswa dalam meningkatkan hasil belajar. Penggunaan virtual lab dapat membuat proses belajar Fisika lebih interaktif dan menarik, sehingga mampu mencapai tujuan pembelajaran dengan efektif dan efisien. Hal ini dikarenakan minat memiliki peranan penting dalam dimensi berpikir terutama pada proses pembelajaran (Tuah, n.d.). Dengan meningkatkan minat belajar maka hasil belajar turut meningkat ditunjukkan berdasarkan hasil tes belajar kognitif yang meningkat.

Penelitian yang dilakukan oleh (Abdul, 2021) mengenai meningkatnya minat belajar siswa menggunakan virtual lab pada pembelajaran Fisika materi optik di masa pandemi. Dapat ditarik kesimpulan bahwa penggunaan virtual lab dapat menjadi solusi dalam meningkatkan proses pembelajaran Fisika, khususnya materi optik. Hal tersebut diperkuat dengan respon siswa saat pembelajaran Fisika menggunakan virtual lab, dengan hasil respon menyenangkan 96,88\%, berminat belajar menggunakan virtual lab 90,63\% dan tes hasil belajar tergolong mudah dengan persentase $87,5 \%$. Sejalan dengan respon siswa, hasil belajar siswa mengalami peningkatan. Serta dengan menggunakan virtual lab, pembelajaran pada materi Optik di masa pandemi berjalan efektif. Sejalan dengan pernyataan (Yuliatun, 2019), menyatakan minat atau kemauan memiliki peran penting dalam kegiatan pembelajaran. Apabila minat atau kemauan belajar siswa tinggi maka berdampak terhadap aktivitas pembelajaran yang menyenangkan sehingga siswa dapat dengan mudah menerima dan materi yang diberikan oleh guru.

Penelitian yang dilakukan oleh (Asshalihin, 2021) mengenai minat belajar Fisika menggunakan media virtual lab di SMAN 10 Pontianak. Hasil angket minat belajar Fisika yang diberikan kepada siswa, menunjukan hasil persentase penggunaan virtual lab saat pembelajaran Fisika memiliki minat belajar lebih tinggi, dengan interpretasi tinggi sebesar 21,4\% (jumlah frekuensi 6), interpretasi sedang 53,5\% (jumlah frekuensi 15\%) dan interpretasi rendah sebesar 17,9\% (jumlah frekuensi 5). Dapat disimpulkan bahwa penggunaan virtual lab memberikan pengaruh positif dengan meningkatnya minat belajar siswa. Pembelajaran menggunakan virtual lab pada materi fluida memberikan kategori sedang untuk minat belajar, sedangkan minat belajar rendah dibandingkan tidak menggunakan virtual lab. Dalam meningkatnya minat belajar siswa tak lepas dari pemilihan dan penggunaan media pembelajaran, khususnya pemilihan media virtual lab di masa pandemi dirasa efektif dengan fungsi pokok media pembelajaran. sejalan dengan pernyataan (Sumiharsono \& Hasanah, 2017), bahwa media pembelajaran adalah alat bantu yang digunakan dalam mewujudkan suatu pembelajaran yang efektif.

Penelitian yang dilakukan oleh (Faris \& Dwikoranto, 2021), mengenai analisis motivasi belajar siswa menggunakan virtual lab di masa pandemi pada materi Fisika Hukum Hooke. Hasil kuesioner yang diberikan kepada siswa sebagai responden untuk mengetahui motivasi belajar Fisika menggunakan virtual lab, didapatkan hasil bahwa tidak ada siswa yang berada di kategori motivasi sangat rendah dan rendah. Sebanyak 6 dari 93 siswa, dengan jumlah persentase 6,5\% berada pada kategori motivasi sedang. 
Sebanyak 74 dari 93 siswa dengan persentase 79,6\% berada di kategori motivasi belajar tinggi. Sebanyak 13 dari 93 siswa, dengan jumlah persentase 14\% memiliki kategori motivasi belajar Fisika menggunakan virtual lab sangat tinggi. Kemudian didapatkan hasil rata-rata kuis setelah menggunakan virtual lab pada materi Hukum Hooke, menyatakan siswa terindikasi memiliki motivasi belajar Fisika yang menggunakan virtual lab pada kategori baik, dengan kategori motivasi berada pada jangkauan sedang hingga sangat tinggi. Sehingga dapat disimpulkan bahwa dengan menggunakan virtual lab untuk mendukung proses pembelajaran, dapat meningkatkan motivasi belajar siswa sehingga siswa dapat memperoleh hasil belajar yang lebih baik. Hal tersebut sejalan dengan pernyataan (Rasyid \& Rohani, 2018) penggunaan media pembelajaran yang tepat dapat meningkatkan perhatian belajar siswa sehingga dapat meningkatkan motivasi belajar siswa. Penggunaan virtual lab juga dianggap efektif dan efisien selama pandemi Covid19 karena bisa menangani pembelajaran yang tidak bisa dilakukan secara tatap muka. Dengan virtual lab pada pembelajaran Fisika siswa dapat dengan mudah memahami konsep hukum yang berlaku sesuai dengan praktikum.

\section{Kesimpulan}

Hasil dari beberapa analisis literatur artikel jurnal disimpulkan bahwa, penggunaan media virtual lab pada pembelajaran Fisika dikatakan efektif pada masa pandemi. Efektivitas penggunaan virtual lab dibuktikan dengan meningkatnya minat belajar dan motivasi siswa. Hal tersebut berdampak juga pada hasil belajar yang meningkat. Serta berbantuan virtual lab memudahkan proses pembelajaran dalam pemahaman konsep Fisika pada materi yang diberikan.

\section{Referensi}

Abdul, K. (2021). Peningkatan Minat Belajar Siswa Melalui Penggunaan Virtual Lab pada Pembelajaran Fisika Masa Pandemi Materi Optik di Kelas XI Mipa 1 SMA Negeri 1 Puri (Best Practice). 6(2).

Adi, P. W., Martono, T., \& Sudarno. (2021). Sekolah Selama Pandemi di Indonesia (Suatu Studi Pustaka). 7(2), 464-473.

Anitasari, B., Winarti, A., \& Rusmansyah, R. (2019). Media Simulasi Phet (Physics Education Technology) untuk Mereduksi Miskonsepsi Siswa pada Konsep Asam Basa. Quantum: Jurnal Inovasi Pendidikan Sains, 10(1), 8. Https://Doi.Org/10.20527/Quantum.V10i1.5713

Asshalihin. (2021). Penggunaan Media Virtual Lab Terhadap Minat Belajar Fisika Peserta Didik SMA Negeri 10 Pontianak.

Dewa, E., Maria Ursula Jawa Mukin, \& Oktavina Pandango. (2020). Pengaruh Pembelajaran Daring Berbantuan Laboratorium Virtual Terhadap Minat dan Hasil Belajar Kognitif Fisika. JARTIKA Jurnal Riset Teknologi Dan Inovasi Pendidikan, 3(2), 351-359. Https://Doi.Org/10.36765/Jartika.V3i2.288

Faris, M., \& Dwikoranto. (2021). Analysis Of Students 'Learning Motivation Using a Virtual Laboratory During Covid- 19 Pandemic On Hooke 'S Law Muhammad Faris, Dwikoranto. 10(1), 131-136.

Giancoli, D. C. (2005). Physics: Principles With Applications (6th Ed.).

Handayani, P. H., Tapilouw, F. S., \& Wulan, A. R. (2018). Peningkatan Sikap Ilmiah Siswa Melalui 
Pembelajaran Berbasis Praktikum Virtual Invertebrata. Jurnal Pelita Pendidikan, 6(1), 13-19. Https://Doi.Org/10.24114/Jpp.V6i1.9142

Hanifah Salsabila, U., Irna Sari, L., Haibati Lathif, K., Puji Lestari, A., \& Ayuning, A. (2020). Peran Teknologi dalam Pembelajaran di Masa Pandemi Covid-19. Al-Mutharahah: Jurnal Penelitian dan Kajian Sosial Keagamaan, 17(2), 188-198. Https://Doi.Org/10.46781/Al-Mutharahah.V17i2.138

Hasanah, N. (2016). Meta-Analisis Kualitatif Skripsi Mahasiswa Berbasis Inkuiri Database Jurusan Biologi Unnes 2014. Universitas Negeri Semarang.

Hendra, J. (2015). Perancangan Media Praktikum Elektronika Digital Berbasis Virtual. 5(December), $118-138$.

Kemdikbud. (2020). Kepmendikbud Nomor 719/P/2020 Tentang Pedoman Pelaksanaan Kurikulum pada Satuan Pendidikan dalam Kondisi Khusus. www.kemdikbud.go.id, (022651), 9. Retrieved From Https://Www.Kemdikbud.Go.Id/Main/Blog/2020/08/Kemendikbud-Terbitkan-Kurikulum-DaruratPada-Satuan-Pendidikan-Dalam-Kondisi-Khusus

Rahma, A. A. (2020). Efektivitas Penggunaan Virtual Lab Phet Sebagai Media Pembelajaran Fisika Terhadap Hasil Belajar Siswa. 6948(3), 47-51.

Rasyid, K.-K. I., \& Rohani. (2018). Manfaat Media dalam Pembelajaran. 91-96.

Saryono, \& Ahmad, R. (2011). Meta Analisis Pengaruh Pembelajaran Pendekatan Taktik (TGFU) Terhadap Pengembangan Aspek Kognitif Siswa dalam Pendidikan Jasmani. Jurnal Pendidikan Jasmani Indonesia, 8(2), 144-151.

Sumiharsono, R., \& Hasanah, H. (2017). Media Pembelajaran. Jawa Timur: CV Pustaka Abadi.

Syamsul, H. (2006). Metodologi Penelitian Kuantitatif untuk Akuntansi dan Keuangan. Yogyakarta: Ekonisia.

Tuah, D. Dan S. (N.D.). Penerapan Media Interaktif pada Era Revolusi. 26-31.

Yuliatun, N. (2019). Pengaruh Media Animasi pada Model Pembelajaran CTL (Contextual Teaching Learning) Terhadap Minat Belajar Peserta Didik Kelas 4 SDN Kleco 2 Surakarta Tahun Pelajaran 2018/2019. Universitas Muhammadiyah Surakarta. 